\title{
Flood vulnerability mapping using frequency ratio (FR) model: a case study on Kulik river basin, Indo-Bangladesh Barind region
}

\author{
Debabrata Sarkar ${ }^{1} \cdot$ Prolay Mondal $^{1}$
}

Received: 23 July 2019 / Accepted: 18 November 2019 / Published online: 30 November 2019

(C) The Author(s) 2019

\begin{abstract}
Flood is a natural but inevitable phenomenon occurring over the period of time. It not only damages the life, property and resources, but also hampers the economy of a nation. In this paper, an attempt has been made to delineate flood vulnerability areas for Kulik river basin through frequency ratio model. Parameters like slope, elevation, rainfall, drainage density, land use-land cover, TWI, population density, road density and household density were endorsed for understanding flood mechanism. In general, 70 (70\%) flood locations from flood inventory map were randomly selected for constructing flood vulnerability map parameters and the rest 30 (30\%) flood locations were used for justifying the outcomes. Flood vulnerability zone map was classified into five zones such as very low $\left(2.02 \mathrm{~km}^{2}\right)$, low $\left(2.45 \mathrm{~km}^{2}\right)$, moderately low $\left(2.44 \mathrm{~km}^{2}\right)$, high vulnerable $\left(2.26 \mathrm{~km}^{2}\right)$ and very high vulnerable $\left(1.21 \mathrm{~km}^{2}\right)$ area. As the AUC value for success rate is 0.901 , the constructed flood vulnerable map with FR model is very much accurate for this river basin. The outcome of this paper will help the planners and decision-makers to take some probable measure to minimize flood vulnerability in this region.
\end{abstract}

Keywords Kulik river basin $\cdot$ Flood $\cdot$ Vulnerability $\cdot$ Frequency ratio (FR) model $\cdot$ Receiver operating characteristic (ROC)

\section{Introduction}

Across the globe in every year, different kinds of natural as well as man-induced hazards and disasters like floods, earthquakes and landslides are causing a large amount of life loss and property damage (Youssef et al. 2011; Du et al. 2013; WHO 2003; Tehrany et al. 2017). Floods occur when there is an overflow of huge volume of water beyond its normal limits, causing inundation of river banks and water stagnation for temporary season. Floods play a role of prime mover for damaging environmental ecosystem, transport system, agriculture and farming, and sociocultural hereditament and altering human life (Billa et al. 2006; Yu et al. 2013; Messner and Meyer 2006; Rahmati et al. 2016a, b, c, d). An immense number of research works have been done on classifying different types of floods and their short- and long-term effects. Magnitude of flood is one of the major

Debabrata Sarkar

debabratas077@gmail.com

Prolay Mondal

mon.prolay@gmail.com

1 Department of Geography, Raiganj University, Raiganj, West Bengal 733134, India factors that determine its impacts. In estimating all inclusive impacts, the direct or indirect damages due to floods can be stratified into materialistic and non-materialistic things (Li et al. 2012; Merz et al. 2004; Smith and Ward 1998). Throughout the globe, floods are considered the major catastrophic events that occur suddenly, causing huge money, health and wealth loss. In between 1963 and 1992, among the different kinds of hazardous events floods are causing $32 \%$ of damage to human and environment. In Orissa and Andhra Pradesh, high-catastrophic sudden flood causes huge amount of property and life loss (Dhar et al. 1981a; WMO 1994; Dhar and Nandargi 2003). Failure of dam due to sudden heavy precipitation has stimulated flood downstream. In 1979, Morvi town of Saurashtra discern uncountable loss of property, crops, livestock and about 10,000 human lives due to Machhu dam failure (Dhar et al. 1981b; Dhar and Nandargi 2003). Uncertainty in climatic condition in Iran persuades a vast number of flooding events throughout the year. The financial vandalization amount escalates to 1705 thousand dollars ascribed to flooding situation in the past decade (Norouzi and Taslimi 2012; Khosravi et al. 2016). India is situated under highly inconsistent monsoon climate, a large number of rivers flow through all over the country, and a heavy downpour of rains for a prolonged time can 
persuade flooding condition. According to Central Water Commission 2010, India is the second largest flood-prone country after Bangladesh with about 40 million hectares of land under flood prone. In every year in India on an average 7.6 million hectares of land is affected by floods. Statistical data provided by CWC divulge that in India flood causing around 200 billion dollars worth of capital loss and 92,000 people died in between 1953 and 2009 (CWC 2010). Every year, people died due to this calamity all over the Earth, an approximately $20 \%$ of world's people died in India. Around 1500 peoples lost their lives, and in average 3 cores of peoples are affected by flood in every rainy season in India (Gupta et al. 2003; Singh and Kumar 2013; Sing and Kumar 2017). As flooding is a terrific natural disaster and it is almost impossible to prevent it completely (Cloke and Pappenberger 2009), it is very necessary to create flood susceptibility mapping and flood vulnerability assessment through which we will be able to design some management schemes for diminishing vandalization of flood in time to come in the future and it is a utilitarian tool to direct the governments and planners to formulate proper flood management plans (Esteves 2013; Haghizadeh et al. 2017; Kia et al. 2012; Khosravi et al. 2016; Feng and Wang 2011; Tehrany et al. 2015; Samanta et al. 2018a, b). Different kinds of parameters like climate and geomorphological structure regulate the occurrence of flood and its intensity. The multi-criteriabased flood susceptibility and vulnerability estimation will much more reliable and validate instead of single criterionbased flood susceptibly analysis (Booij 2005; Minea 2013; Tehrany et al. 2014a, b; Xu et al. 2013; Poussin et al. 2014). In majority of the cases, flood management plan means strategies taken for distributing reliefs and resettling floodaffected people. Flooding prediction, preparation according to flood predictability, implementing strategies during flood, and overall damage assessment are the major four steps for flood management (Konadu and Fosu 2009). Now, in recent decades, remote sensing (RS) and GIS software techniques are intensely used as they provide a brand new dimension for vulnerability assessment with proper justification. Analysing satellite imageries on RS and GIS platform assigned satisfactory results for flood susceptibility and vulnerability mappings as it is providing flawless information about a region (Ali et al. 2019). It creates an amazingly pleasant environment where a wide variety of models can run and manipulate information to evaluate flood vulnerability, and the results become more logical and acceptable. At the present time, RS and GIS techniques are being used very successfully for flood vulnerability all over the world (Khosravi et al. 2016; Dewan et al. 2007; Haq et al. 2012). There are so many models and techniques alternatively used for flood vulnerability mapping. Frequency ratio (FR) model (Lee et al. 2012) is one of the highly acceptable techniques for hazards assessment with high accuracy rate. Frequency ratio (FR) is a one kind of bivariate statistical analysis (BSA), and this method gives value to every single class of each parameter and evaluates its impact on flood occurrence (Jebur et al. 2014; Tehrany et al. 2017). FR model is a simple process to run on GIS environment and can construct scientifically valid flood vulnerably map (Tehrany et al. 2014a, b; Liao and Carin 2009; Samanta et al. 2018a, b). RS- and GIS-like sophisticated software provides an easy way for preparing flood susceptibility mapping by FR model. The main objective of the present research is to prepare flood vulnerability map of Kulik river basin by using FR model. The objective of this work is to critically analyse flood risk potential zone of Kulik river basin.

\section{Study area}

The latitudinal and longitudinal extensions of Kulik river basin are $25^{\circ} 32^{\prime} 00^{\prime \prime} \mathrm{N}$ to $26^{\circ} 10^{\prime} 06^{\prime \prime} \mathrm{N}$ and $87^{\circ} 60^{\prime} 00^{\prime \prime} \mathrm{E}$ to $88^{\circ} 24^{\prime} 56^{\prime \prime} \mathrm{E}$, respectively. Kulik river basin is situated in the mature alluvium of Indo-Bangladesh Barind tract. The maximum height of the Kulik river basin is $71 \mathrm{~m}$ which has been observed in the source segment of the Kulik River, and the minimum height is only $17 \mathrm{~m}$ which is found in the confluence point. The Kulik River originated in the Thakurgaon District of Bangladesh which flows $133.27 \mathrm{~km}$ and joins the Nagar River in Itahar CD Block of Uttar Dinajpur, India. Since the difference between the highest and lowest altitude is only $54 \mathrm{~m}$, it is very easy to assume that the Kulik River flows over a flat region. Total area of the Kulik river basin is $1038.51 \mathrm{~km}^{2}$. A decrease in water carrying capacity of river due to aggradations and rainfall during monsoon is the main reason for flooding in this region. Although some of the measures are taken to prevent flood in some places, like plantation along the river side, they are less than necessary, so every year flood causes huge damage to property and life. Evidences collected from USGS toposheet (1951) show that, before 1951, Kulik River drains its water to Mahananda River directly, but due to some tectonic movement triggers now Kulik River merged with Nagar River, and after flowing to some distance Nagar River merged with Mahananda River (Sarkar and Pal 2018). About 281 numbers of oxbow lakes and paleo-channels along the both sides of Kulik River defined its migratory behaviour in nature (Sarkar 2018). Due to the fact that the river basin is in the plain region, a large number of lowlands in the form of oxbow lakes, ponds and paleo-channels scatteredly located all over the basin create an ideal condition for flooding. This region has an annual rainfall of $2280 \mathrm{~mm}$ and located under sub-humid monsoonal climate. This region receives about $80 \%$ of all rainfall from the month of June to October. This region is often flooded by floods due to excessive rainfall in this short 
period (Sarkar and Pal 2018). Figure 1 shows the flood-inundated area on 24 June 2017.

\section{Data source and methodology}

For flood vulnerability mapping of Kulik river basin, nine individual parameters were taken into consideration. Table 1 shows the detail specification of different data sets and their characteristics. All the layers have been constructed and combined in ArcGIS (v.10.3.1) environment and Fig. 2 showing the flowchart and methodology for preparing flood vulnerability mapping of Kulik river basin. Slope map, elevation map and TWI map have been constructed from SRTM DEM data (Table 1). The land use-land cover (LULC) map has been prepared using maximum likelihood classifier method. All stream segments have been digitized from Google Earth image for construction of drainage density map in ArcGIS (v.10.3.1) platform. Road density map also is extracted from the same source using hand-held GPS tracking system which can be used wherever it is needed. Population and household data have been collected from official census website (Census 2011) of both countries. A field inspection during flood and post-flood study has been conducted (June-August 2017) for assessing probable causes, damages due to
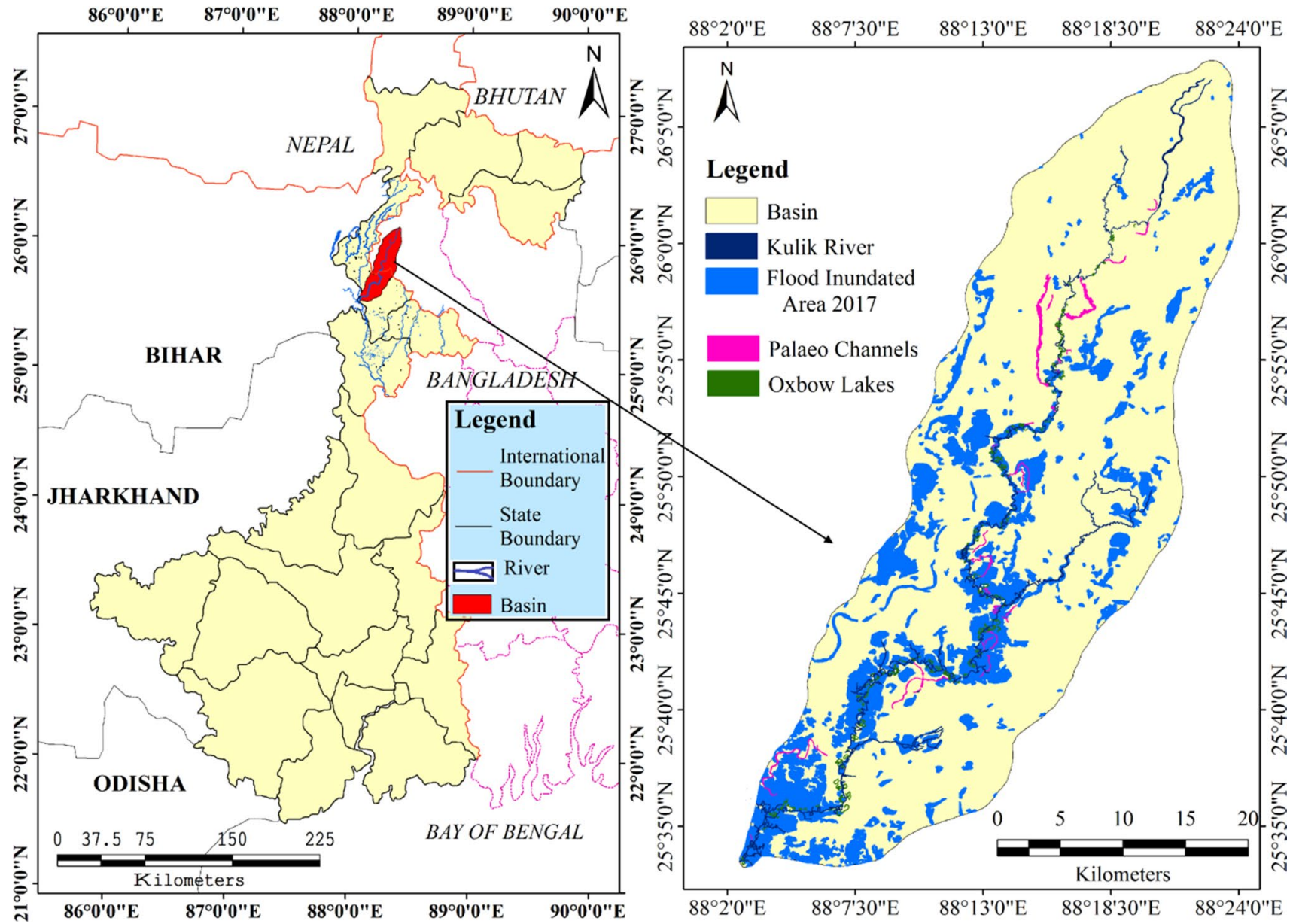

Fig. 1 Location of the study area

Table 1 Data source and data type used in the research work

\begin{tabular}{lllll}
\hline Sl. no. & Data description & Data type/resolution & Year & Source \\
\hline 1 & LANDSAT-8 OLI & Satellite image & 2018 & USGS \\
2 & ASTER DEM & $30 \mathrm{~m}$ & 2018 & USGS \\
3 & Rainfall & Point data & 2018 & Data collected from weather station, \\
& & & 2018 & Cecondary source \\
4 & Population & - & &
\end{tabular}


Fig. 2 Flow chart and methodology for preparing flood vulnerability map

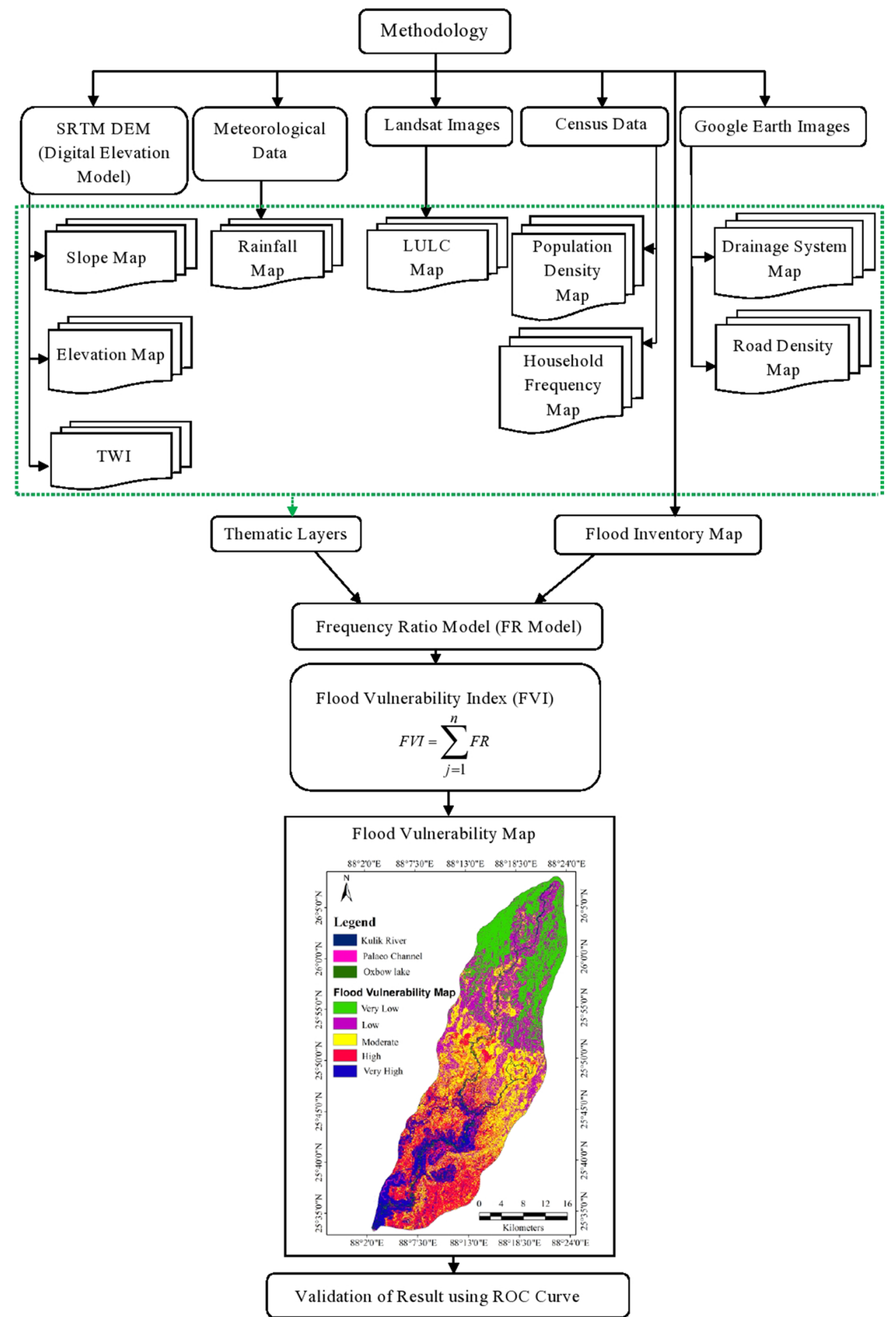

flooding and people's perception about this threatening calamity.

\section{Flood inventory map}

For analysing flood vulnerability, it is extremely important of having a scientifically justified past flood occurrence data for estimating future flood (Manandhar 2010). The correctness and reliability of the future flood vulnerability hinge on the precision of the previously recorded flooding events (Merz et al. 2007). For Kulik river basin, flood 


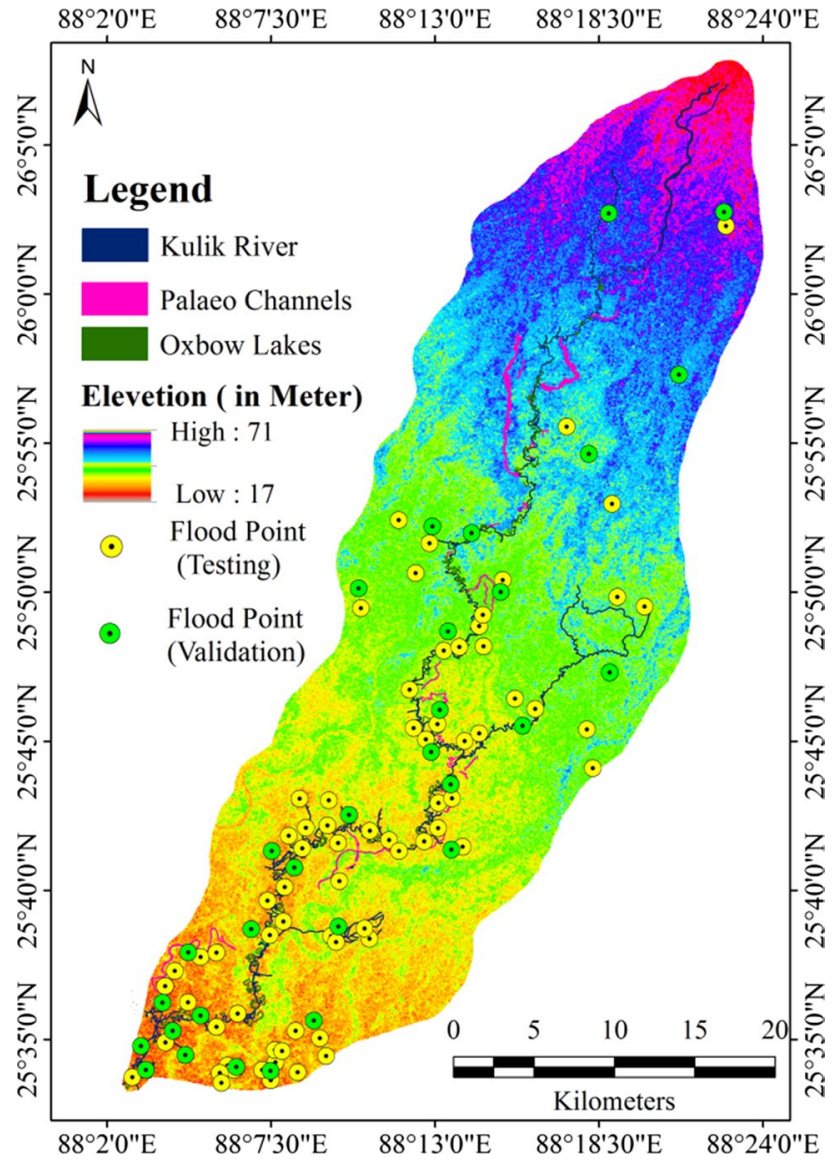

Fig. 3 Flood inventory map of Kulik river basin

inventory map has been prepared based on 2017 extreme flood event (geoapps.icimod.org/BD2017) on ArcGIS 10.3.1 environment (Fig. 3). A total of 100 flood points are randomly divided into two groups of training and validation data sets for preparing and justifying the result of flood vulnerability.

Though there are no specific rules for defining how flood point will be allocated into training and validation data sets (Pradhan and Lee 2010), usually research work has been done by using $70 \%$ of floods events as training data set for preparing flood vulnerability model and the rest 30\% have been used for validation of the output model (Ohlmacher and Davis 2003; Tunusluoglu et al. 2008; Pourghasemi et al. 2012; Pourghasemi and Beheshtirad 2014). In this research work, 70 (70\%) training points were randomly nominated for flood modelling and $30(30 \%)$ validation points have been used for authentication of the model (Rahmati et al. 2016a, c).

\section{Flood conditioning factors}

There are so many geo-environmental and man-made independent factors controlling flood occurrences in a region (Tehrany et al. 2015). So for investigating flood risk assessment it is strategically important to select appropriate factors to get reliable outcomes because an individual flood controlling factor may be very much functional in a specific catchment, but in other areas it may not be necessary (Kia et al. 2012). For the present research work, totally nine conditioning factors such as (1) slope, (2) elevation, (3) drainage density, (4) rainfall, (5) LULC, (6) topographical wetness index (TWI), (7) road density, (8) population density and (9) household frequency are taken into consideration.

Slope and elevation maps (Fig. 4a, b) of the study area have been prepared from DEM by using ArcGIS software (Khosravi et al. 2016; Tehrany et al. 2017). Slope and elevation are most important factors for flood vulnerability assessment. Land elevation always plays an important and effective role for contriving flood vulnerability mapping (Rahmati et al. 2016a, c; Fernandez and Lutz 2010). The climate of the region is regulated by the variability of the height of the land in that region (Samanta et al. 2012). Different altitudinal zones receive different amounts of rainfall and temperature; as a result, it creates different types of vegetation cover and soil forms (Aniya 1985). Slope is one of the principle components of flooding (Mishra 2013; Haghizadeh et al. 2017). Land slope controls the surface water flow, vertical infiltration process (Youssef et al. 2011) and rate of soil erosion (Adiat et al. 2012) of a region.

Drainage density has a great significant impact on flood occurrence. It has a positive correlation with flooding as a large number of streams raise the flood potentiality multiplied by it. For preparing rainfall map (Fig. 4d), rainfall values put against seven weather stations, i.e. Slilguri, Islampur, Dalkhola, Raiganj, Raghunathpur (India) and Thakurgaon and Dinajpur (Bangladesh), and by using IDW (inverse distance weighting) in ArcGIS environment rainfall map of the study area has been constructed.

Different types of LULC of a region control flood vulnerability differently. Vegetation cover has a negative relation with flood as it slows down surface water flow and recharging groundwater by promoting infiltration process (Rahmati et al. 2016a, b, c, d; Tehrany et al. 2013a, b). On the other hand, built-up area with high surface run-off creates flooding condition. LULC map was constructed from Landsat 8 OLI imageries. Supervised image classification is done by using maximum likelihood classifier algorithm of ERDAS Imagine (v.9.1) (Samanta 2013).

Topographical wetness index (TWI) is also known as compound topographical index (CTI). TWI technique is

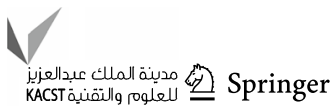



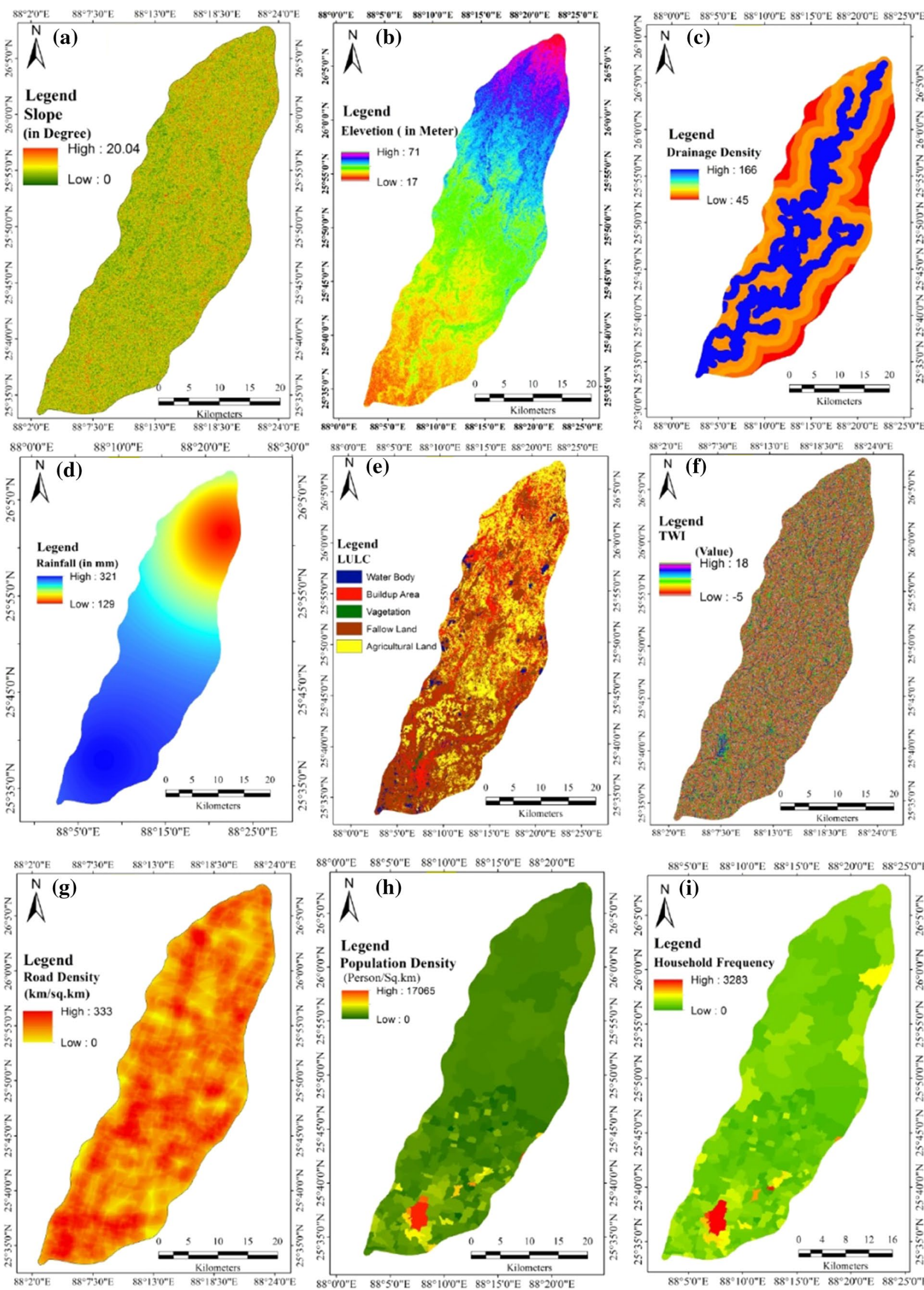

$8^{\circ} 5^{\circ} 0^{\prime \prime} \mathrm{E} \quad 88^{\circ} 10^{\circ} 0^{\circ} \mathrm{E} \quad 88^{\circ} 150^{\circ} \mathrm{E} \quad 88^{\circ} 20^{\circ} 0^{\prime \prime} \mathrm{E} \quad 88^{\circ} 25^{\circ} 0^{\prime \prime} \mathrm{E}$

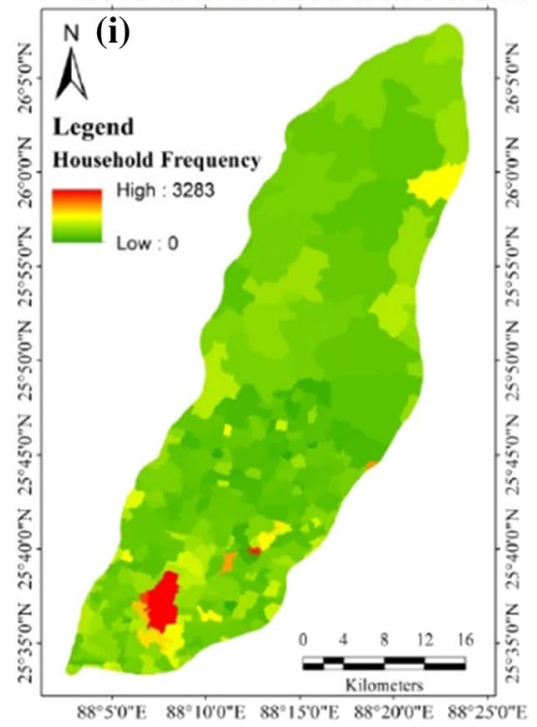


४Fig. 4 a-i Spatial data layers used for preparing flood vulnerability mapping: a slope, b elevation, $\mathbf{c}$ drainage density, $\mathbf{d}$ rainfall, e LULC, $\mathbf{f}$ TWI, $\mathbf{g}$ road density, $\mathbf{h}$ population density, $\mathbf{i}$ household frequency

used to understand the topographical influence on the rate of wetness of a catchment area and to show the rate of over land flow (Samanta et al. 2018a, b). Amount of flow accumulation at any point in the catchment area can be calculated by TWI technique, and it shows the flow of water under the influence of gravity (Moore et al. 1991). TWI is a very effective technique for analysing flood potentiality (Rahmati et al. 2016a, b, c, d; Haghizadeh et al. 2017; Samanta et al. 2018a, b; Khosravi et al. 2016; Ali et al. 2019; Tehrany et al. 2015, 2017). TWI map has been constructed from DEM by running flowing equation on Raster Calculator in ArcGIS environment (Regmi et al. 2010; Moore et al. 1991; Jaafari et al. 2014; Nampak et al. 2014; Ali et al. 2019):

TWI $=[\operatorname{Ln}($ FLOWACC $* 900 / \tan (\beta))]$,

where FLOWACC is the flow accumulation derived from DEM in ArcGIS environment and $\beta$ is the slope (in ${ }^{\circ}$ ).

For preparing road density map, all major roads of Kulik river basin have been extracted by manual digitization process from Google Earth image and imported to ArcGIS (v10.3.1). Road has a significant effect on flooding as it works as an artificial barrier in the way of flood. To some extent, high road density reduces the destruction process of flood. The horrors of floods were measured by judging environmental and societal aspects. Extreme flood events leave the evidence of huge loss of property, houses and death every year around the world. In densely populated areas, the number of deaths increases in multiples by flooding.

\section{Bivariate statistical analysis (frequency ratio model)}

Assessment of flood vulnerability mapping is very much essential to identify the factors affecting flood. The relationship between flood and associated conditioning factors that can trigger flood could be derived from the past flooding events and their causing parameters. In the present study, frequency ratio (FR) model has been used to construct flood vulnerability mapping of Kulik river basin. FR is a BSA method that critically analyses the contribution of every class of each conditioning factor on future flooding (Lee et al. 2012). FR is calculated by analysing the relationship between flood occurrences and the attributed factors. So FR of every class of each conditioning factor has been calculated with respect to previous flood event as shown in Table 2. FR values were calculated by using the following formula:
$\mathrm{FR}=\left[N_{\text {pix }}\left(\mathrm{SX}_{i}\right) / \sum_{i=1}^{m} \mathrm{SX}_{i}\right] /\left[N_{\text {pix }}(X j) / \sum_{j=1}^{n} N_{\text {pix }}\left(X_{j}\right)\right]$.

After calculating FR values of every class, each controlling factor summed up all the values for generating final flood vulnerability map. The formula of flood vulnerability map given below:

$\mathrm{FVI}=\sum_{j=1}^{n} \mathrm{FR}$,

where $N_{\text {pix }}\left(\mathrm{SX}_{i}\right)$ is the number of flood points in class $i$ of variable $X, N_{\text {pix }}\left(X_{j}\right)$ is the number of pixels in variable $X_{j}, m$ is the total classes in the variable $X_{i}$, and $n$ is the total factors of the study area (Regmi et al. 2013; Jaafari et al. 2014).

FR is one of the simplest and authentic methods frequently applied for flood vulnerability mapping all over the world (Yilmaz 2007; Khosravi et al. 2016; Rahmati et al. 2016a, b, c, d; Samanta et al. 2018a, b). If the FR value is greater than 1 , it means parameters are strongly influencing flooding, and if it is below 1 it shows the negative relationship between flood occurrence and controlling variables (Lee and Talib 2005; Pradhan 2010; Sujatha et al. 2013; Akgun et al. 2008; Mondal and Maiti 2013).

\section{Results and discussion}

Tables 2 and 3 show the weights of different sub-classes of each of the nine conditioning factors in reference to flood vulnerability mapping. Flood occurrence parameters like slope, elevation, drainage density, rainfall, LULC and TWI have been calculated based on the FR model (Table 2), and road density, population density and household frequency layers are constructed in reference to five-point rating scale (Table 3). High frequency ratio (FR) value is stipulating high flood probability. So a high positive correlation exists in between frequency ratio (FR) and flooding phenomena (Tehrany et al. 2013a, b).

The slope of a region regulates the flood occurrence as low flat plain area has a strongly association with flooding condition in the rainy season. A high number of floods occur in lower slope area as the water cannot discharge swiftly. Slope between $0^{\circ}$ and $10.59^{\circ}$ supports the fact of flooding as the FR value is considerably more than one (Tehrany et al. 2017). High slope indirectly enhances the flood probability as it fosters speedy water and the area with high slope has the less time to regulate and percolate water under the ground (Jaiswal et al. 2003). In Kulik river basin, the outcome exhibits that the FR value is more than 1 in the first two slope sub-classes $0^{\circ}-1.18^{\circ}$ and $1.18^{\circ}-2.12^{\circ}$ and the FR

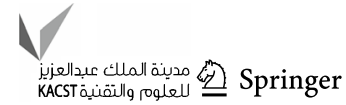


Table 2 Rating of parameters used for vulnerability mapping through FR model
Table 3 Assignment of weight to sub-class of individual parameters used for vulnerability mapping through five-point rating scale

\begin{tabular}{|c|c|c|c|c|c|c|}
\hline Factors & Class & Total pixel & $\%$ of area & Flood pixel & $\%$ of area & FR \\
\hline \multirow[t]{5}{*}{ Slope (in ${ }^{\circ}$ ) } & $0-1.18$ & 310,406 & 26.122 & 60,568 & 29.71 & 1.14 \\
\hline & $1.18-2.12$ & 402,832 & 33.900 & 72,458 & 35.54 & 1.05 \\
\hline & $2.12-3.38$ & 324,718 & 27.326 & 51,339 & 25.18 & 0.92 \\
\hline & $3.38-4.88$ & 125,458 & 10.558 & 16,485 & 8.09 & 0.77 \\
\hline & $4.88-20.04$ & 24,887 & 2.094 & 3002 & 1.47 & 0.70 \\
\hline \multirow[t]{5}{*}{ Elevation } & $17-27.8$ & 930 & 0.08 & 795 & 0.39 & 4.98 \\
\hline & $27.8-38.6$ & 364,271 & 30.65 & 127,260 & 62.43 & 2.04 \\
\hline & $38.6-49.4$ & 526,380 & 44.30 & 69,698 & 34.19 & 0.77 \\
\hline & $49.4-60.2$ & 273,940 & 23.05 & 6052 & 2.97 & 0.13 \\
\hline & $60.20-71$ & 22,780 & 1.92 & 47 & 0.02 & 0.01 \\
\hline \multirow[t]{5}{*}{ Drainage density } & $<45$ & 435,463 & 36.65 & 124,457 & 61.05 & 10.67 \\
\hline & $45-58$ & 295,848 & 24.90 & 33,434 & 16.40 & 0.66 \\
\hline & $58-65$ & 205,596 & 17.30 & 24,088 & 11.82 & 0.68 \\
\hline & $65-68$ & 151,487 & 12.75 & 14,136 & 6.93 & 0.54 \\
\hline & $68-166$ & 99,907 & 8.41 & 7735 & 3.79 & 0.45 \\
\hline \multirow[t]{5}{*}{ Rainfall (in mm) } & $129.24-172.93$ & 139,520 & 11.74 & 4972 & 2.44 & 0.21 \\
\hline & $172.93-218.88$ & 155,625 & 13.10 & 5736 & 2.81 & 0.22 \\
\hline & $218.88-260.31$ & 161,790 & 13.62 & 11,742 & 5.76 & 0.42 \\
\hline & $260.31-294.96$ & 269,291 & 22.66 & 55,339 & 27.15 & 1.2 \\
\hline & $294.96-321.33$ & 462,075 & 38.89 & 126,062 & 61.84 & 1.59 \\
\hline \multirow[t]{5}{*}{ LULC } & Water body & 50,876 & 4.28 & 17,170 & 8.42 & 1.97 \\
\hline & Built-up area & 270,809 & 22.79 & 15,925 & 7.81 & 0.34 \\
\hline & Vegetation & 13,450 & 1.13 & 256 & 0.13 & 0.11 \\
\hline & Fallow land & 466,828 & 39.29 & 118,809 & 58.28 & 1.49 \\
\hline & Agricultural land & 386,338 & 32.51 & 51,691 & 25.36 & 0.78 \\
\hline \multirow[t]{5}{*}{ TWI } & -5.7 to 0.53 & 241,891 & 20.36 & 32,132 & 15.76 & 0.77 \\
\hline & $0.53-1.79$ & 466,174 & 39.23 & 68,386 & 33.55 & 0.86 \\
\hline & $1.79-3.33$ & 321,054 & 27.02 & 62,615 & 30.72 & 1.14 \\
\hline & $3.33-5.40$ & 130,915 & 11.02 & 31,932 & 15.66 & 1.42 \\
\hline & $5.40-17.32$ & 28,267 & 2.38 & 8786 & 4.31 & 1.81 \\
\hline
\end{tabular}

\begin{tabular}{lllrrrr}
\hline Factor & Class & Total pixel & \% of area & Flood pixel & \% of area & Rating \\
\hline Road density & $0-66.46$ & 171,611 & 14.44 & 25,991 & 12.75 & 5 \\
& $66.45-132.92$ & 314,493 & 26.47 & 66,080 & 32.42 & 4 \\
& $132.92-199.39$ & 349,458 & 29.41 & 61,918 & 30.37 & 3 \\
& $199.39-265.86$ & 244,640 & 20.59 & 33,400 & 16.38 & 2 \\
Population density & $265.86-332.32$ & 108,099 & 9.10 & 16,462 & 8.08 & 1 \\
& $0-602$ & 140,472 & 11.82 & 58,415 & 28.66 & 1 \\
& $602-1070$ & 862,549 & 72.59 & 120,968 & 59.34 & 2 \\
& $1070-2275$ & 146,024 & 12.29 & 20,984 & 10.29 & 3 \\
Household frequency & $2275-5086$ & 26,930 & 2.27 & 3081 & 1.51 & 4 \\
& $5086-17,065$ & 12,327 & 1.04 & 404 & 0.20 & 5 \\
& $0-162$ & 421,146 & 35.44 & 57,389 & 28.15 & 1 \\
& $162-254$ & 496,546 & 41.79 & 95,519 & 46.86 & 2 \\
& $254-446$ & 219,597 & 18.48 & 47,000 & 23.06 & 3 \\
& $446-1122$ & 38,745 & 3.26 & 3565 & 1.75 & 4 \\
& $1122-3283$ & 12,267 & 1.03 & 379 & 0.19 & 5 \\
\hline
\end{tabular}


value is less than 1 where slope is greater than $2.12^{\circ}$, respectively. About $60 \%$ of flooding occurred in the area having less than $2.12^{\circ}$ of slope (Table 2 ).

Elevation is one of the major controlling factors of flooding. Generally, the FR value will decrease as the height of the area increases. It is exhibited in Table 2 that the two lower elevated areas (17-27.8 $\mathrm{m}$ and 27.08-38.06 $\mathrm{m}$ ) in Kulik river basin have been recorded high FR values of 4.98 and 2.04, respectively, which illustrate the high probability of flooding in low elevated area (Khosravi et al. 2016). Area with low FR value with high altitude has the less probability of flooding. About $63 \%$ of flood (2017) occurred in these two low elevation zones of Kulik River.

Area with low drainage density has the greater chances for flooding; due to low number of drainage systems, water cannot be drained very quickly in a short period of time. In Kulik river basin, the lower drainage density $(<45)$ area recorded almost $61 \%$ of past flooding as the FR value is 0.67 (Table 2).

The amount of rainfall is the most important reason for flooding in any area. No region expects that the rain can be flooded. It is to be observed that the FR value (1.59) is high in places where rainfall is high $(294.96-321.33 \mathrm{~mm})$ (Samanta et al. 2018a, b).

The land use-land cover (LULC) in the region can be used as a very important tool to identify flood-prone areas in a river basin. For example if there is no natural. Forest area acts as a natural resistance to flood prevention in any area. On the other hand, the open field enhances flood trends many times. So there is a positive relationship with the flood in the open wilderness and negative relations with forest cover area (Samanta et al. 2018a, b; Shabani et al. 2014). Again, in built-up area due to concretization the amount of underground water percolation is very negligible but surface run-off of very high. In Kulik river basin, the high FR value recorded in fallow land and agricultural land is 1.49 and 0.78 , respectively (Table 2 ). The outcome supports the fact that unprotected area is highly susceptible for flooding.

The TWI factor is one of the extremely necessary factors for future flood prediction. In the case of Kulik river basin, the topographical wetness index (TWI) is divided into five sub-classes. Normally, it is safe to say that the flood probability is high in the places where the TWI is more (Khosravi et al. 2016). The highest FR value of 1.81 is observed in the class of 5.40-17.31, and the lowest FR value in the class of $-5.7-0.53$.

For preparing flood vulnerability mapping, here road density, population density and household frequency layers are divided into five main categories and given rating from 1 to 5 (Table 3 ) towards vulnerability. The area where the concentration of roads is the highest is given 1 and given 5 where the lowest road concentration found. The road works in an area as an artificial barrier to prevent flooding. Therefore, the more the density of roads is in those areas, the lesser the tendency to flood in those areas. If there is more population density in any area, then the chances of damage to floods in those areas are greatly increased. Here is existing a positive relationship in between population density and flood vulnerability. For preparing flood vulnerability map of Kulik River, maximum class $(>5086)$ is given a maximum of 5 points and the lowest class $(<602)$ is given 1 point. Following the same way of population density, household frequency layer has been prepared and given point to five different sub-classes, respectively. As the number of homesteads in flood-prone area is high, the probability of damage due to floods increases.

\section{Flood vulnerability mapping of Kulik river basin}

After preparing individual layers of nine conditioning parameters and given weights to those parameters, all the parameters are combined to construct the final flood vulnerability map of Kulik river basin on ArcGIS 10.3.1 environment by overlapping process (Fig. 5). The final flood map has been divided into very low (244-433), low (433-562), moderate (562-693), high (693-819) and very high (819-1327) vulnerable zone (Table 4). The result has shown that $2.02(19.48 \%) \mathrm{km}^{2}$ of land is categorized under low flood vulnerability. The low flood vulnerable zone was situated mostly in the high altitude above $50 \mathrm{~m}$ from the mean sea level. Around $2.45(23.64 \%) \mathrm{km}^{2}$ of land is categorized under low vulnerability zone, $2.44(23.45 \%) \mathrm{km}^{2}$ of land under moderately vulnerable, $2.26(21.74 \%) \mathrm{km}^{2}$ of land under high flood zone and $1.21(11.69 \%) \mathrm{km}^{2}$ of land under very high flood vulnerability zone in future. Very high and high flood vulnerable areas are located in the lower segment
Table 4 Flood vulnerability zone of Kulik river basin and area under different sub-zones

\begin{tabular}{llllll}
\hline Zone & Class & Total pixel & \% of pixel & Total area $\left(\mathrm{km}^{2}\right)$ & \% of area \\
\hline Very low & $244-433$ & 231,645 & 19.49 & 2.02 & 19.48 \\
Low & $433-562$ & 279,627 & 23.53 & 2.45 & 23.64 \\
Moderate & $562-693$ & 277,521 & 23.35 & 2.44 & 23.45 \\
High & $693-819$ & 257,688 & 21.69 & 2.26 & 21.74 \\
Very high & $819-1327$ & 141,821 & 11.93 & 1.21 & 11.69 \\
\hline
\end{tabular}




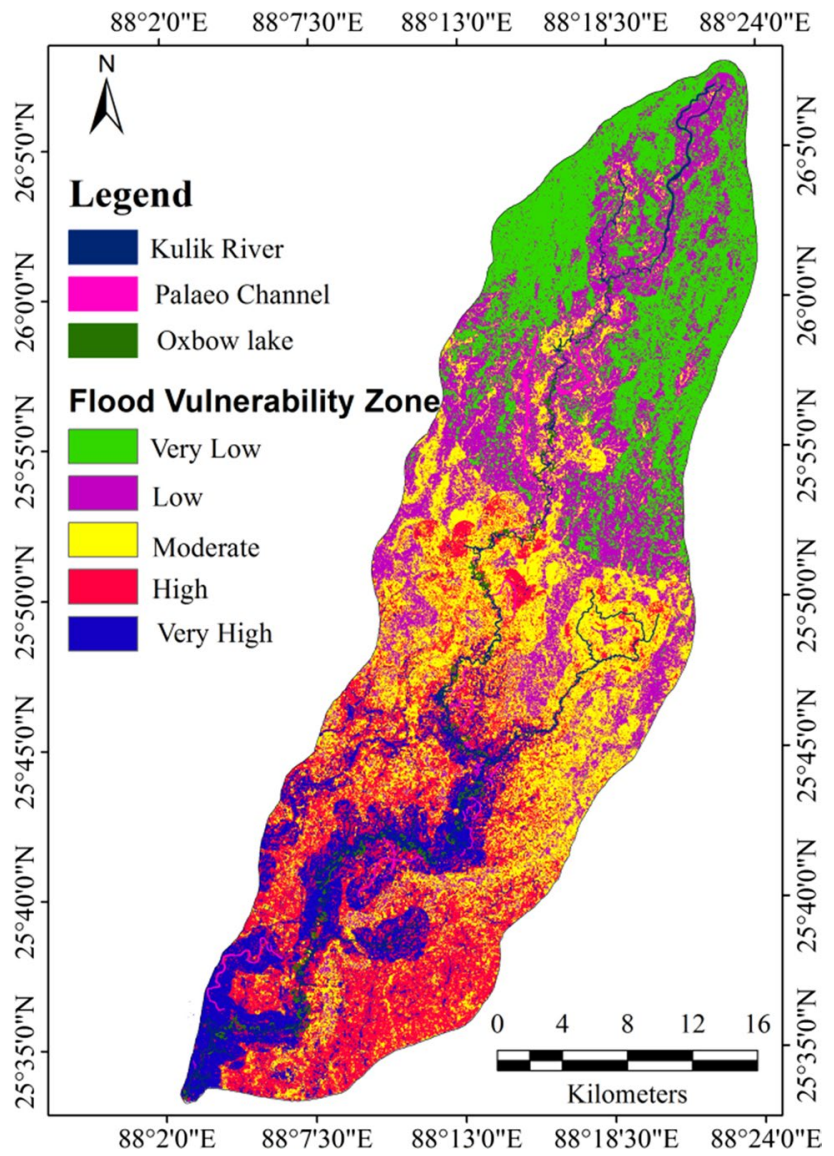

Fig. 5 Flood vulnerability mapping using the FR model

of Kulik river basin. From the final flood vulnerability map, it is clearly identified that peoples living on the banks of Kulik River are most likely to be affected by future floods as this area is situated under very high flood vulnerability zone.

\section{Validation of flood vulnerability map}

After creating a model, it is not the scientific way to use it for governmental or non-government purpose without checking the accuracy and reliability of that model (Chung and Fabbri 2003). In the study area, the receiver operating characteristic (ROC) curve was used to verify flood vulnerability map. This ROC curve system is a simple and universal technique based on scientific basis through which we can accurately assess a test. In ROC curve, false positive rate is shown along the $X$-axis and true positive rate along $Y$-axis. To substantiate the prediction of any model, area under curve (AUC) is taken into consideration as if the AUC value is 0.5 or less than that the model is inappropriate for flood vulnerability mapping and if the value is perfectly 1 then this model is the most suitable for estimating flood trends and if the AOC value is $>0.75$ then flood predictability is

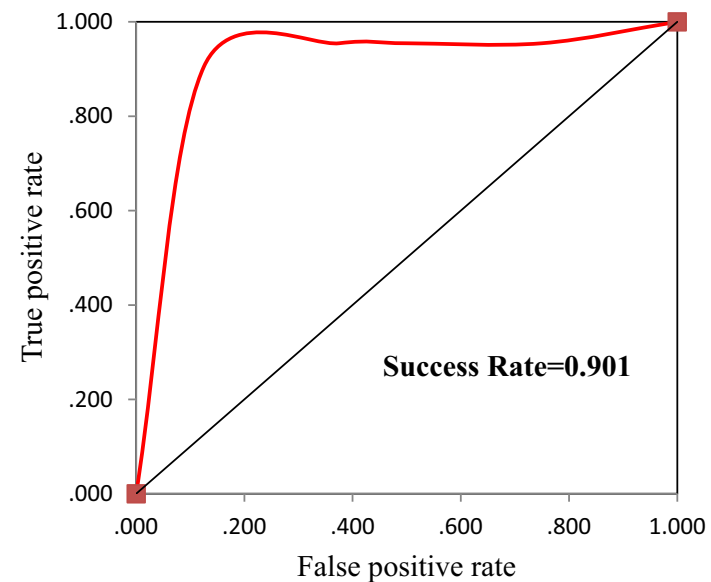

Fig. 6 ROC curve of success rate of the FR model

also well accepted (Saha 2017; Ozdemir and Altural 2013; Akgun et al. 2008; Egan 1975; Pradhan et al. 2010). Based on AOC curve, prediction of model has been classified into five categories as $0.5-0.6$ (poor), 0.6-0.7 (average), 0.7-0.8 (good), 0.8-0.9 (very good) and 0.9-1.0 (excellent) (AlAbadi 2015; Saha 2017). In the present research work, 70 (70\%) flood locations are used for flood vulnerability mapping and $30(30 \%)$ of total data set, which is not incorporated with FVM, are used for justifying the flood vulnerability. The AUC value is 0.901 (Fig. 6). It is very easy to establish that the model used for preparing flood vulnerability mapping of Kulik river basin is quite accurate and suitable for determining flood trends. Consequently, it can be concluded that the FR model is very useful technique for determining flood vulnerability mapping.

\section{Conclusion}

In recent times, among many geo-environmental hazard and disasters, floods are considered the most catastrophic disaster all over the globe. Analysing flood vulnerability mapping is very much significant for diminishing ruinous flood by implementation of fide approaches. Flood vulnerability-related information is a principle asset for planners for implementation of right land use in flood-prone areas. In the present study, a BSA-based FR model espouses to comprehend the interconnection of flood occurrence and factor variables of Kulik river basin. Nine conditioning factors, i.e. slope, elevation, drainage density, rainfall, LULC, topographical wetness index (TWI), road density, population density and household frequency, were taken, and based on the flood inventory map individual layers have been generated with $30 \times 30 \mathrm{~m}^{2}$ resolution. A random sampling technique has been used for selecting $70 \%$ total flood point for layers construction and $30 \%$ for validation purposes. The 
authentication of flood vulnerability mapping relies on how precisely factor layers were prepared. The final flood vulnerability map was classified into five zones, very low, low, moderate, high and very high zone, respectively. Figure 5 shows that very high vulnerable areas were delineated in lower segment adjacent to the river with $1.21 \mathrm{~km}^{2}$ of lands. The ROC curve was used to evaluate the effectiveness of the present FR model for vulnerability mapping and appraise the outcome. The product divulges that the method applied in the present work produces reliable and accurate result with $90.10 \%$ success rate. So it can be concluded that the perfections of the conditioning factors have a noteworthy impact on flood vulnerability mapping as if the standard level of parameters strengthens the performance of the model also increases. The most important parameters and the class for flood vulnerability mapping of Kulik river basin are low slope $\left(0^{\circ}-1.18^{\circ}\right)$, low elevation $(17-27.8 \mathrm{~m})$ and high TWI (5.40-17.32). This model can assist the government, planners and decision-makers to implement proper management schemes in this study area and confined the developmental processes by demarcating flood vulnerable places.

Acknowledgements This research work would never be completed without the contribution of a great few peoples to whom we would like to express our deepest gratitude. Authors would like to acknowledge Dr. Sunil Saha (Assistant Professor, University of Gour Banga) and Gopal Ch. Paul (Research Scholar, University of Gour Banga) for helping and supporting in every step of this work. We would also like to thank peoples who contributed their knowledge and information during field survey.

\section{Compliance with ethical standards}

Conflict of interest The authors hereby declared that there is no conflict of interest.

Open Access This article is distributed under the terms of the Creative Commons Attribution 4.0 International License (http://creativeco mmons.org/licenses/by/4.0/), which permits unrestricted use, distribution, and reproduction in any medium, provided you give appropriate credit to the original author(s) and the source, provide a link to the Creative Commons license, and indicate if changes were made.

\section{References}

Adiat KAN, Nawawi MNM, Abdullah K (2012) Assessing the accuracy of GIS-based elementary multi criteria decision analysis as a spatial prediction tool-a case of predicting potential zones of sustainable groundwater resources. J Hydrol 440-41:75-89

Akgun A, Dag S, Bulut F (2008) Landslide susceptibility mapping for a landslide-prone area (Findikli, NE of Turkey) by likelihoodfrequency ratio and weighted linear combination models. Environ Geol 54:1127-1143

Al-Abadi AM (2015) Modeling of groundwater productivity in northeastern Wasit Governorate, Iraq using frequency ratio and Shannon's entropy Models. Appl Water Sci. https://doi.org/10.1007/ s13201-015-0283-1
Ali SA, Khatun R, Ahmad A, Ahmad AN (2019) Application of GISbased analytic hierarchy process and frequency ratio model to flood vulnerable mapping and risk area estimation at Sundarban region, India. Model Earth Syst Environ. https://doi.org/10.1007/ s40808-019-00593-z

Aniya M (1985) Landslide-susceptibility mapping in the Amahata river basin, Japan. Ann Assoc Am Geogr 75(1):102-114

Billa L, Shattri M, Mahmud AR, Ghazali AH (2006) Comprehensive planning and the role of SDSS in flood disaster management in Malaysia. Disaster Prev Manag 15:233-240

Booij MJ (2005) Impact of climate change on river flooding assessed with different spatial model resolutions. J Hydrol 303:176-198

Central Water Commission (CWC) (2010) Water and related statistics. Water Resource Information System Directorate, New Delhi, pp 198-247

Chung CF, Fabbri AG (2003) Validation of spatial prediction models for landslide hazard mapping. Nat Hazards 30:451-472

Cloke H, Pappenberger F (2009) Ensemble flood forecasting: a review. J Hydrol 375(3):613-626

Dewan AM, Islam MM, Kumamoto T, Nishigaki M (2007) Evaluating flood hazard for land-use planning in greater Dhaka of Bangladesh using remote sensing and GIS techniques. Water Res Manag 21(9):1601-1612

Dhar ON, Nandargi S (2003) Hydro meteorological aspects of floods in India. Nat Hazards 28:1-33

Dhar ON, Mandal BN, Ghose GC (1981a) The Vamsadhara flash flood of September, 1980 a brief appraisal. Vayu Mandalll $3 \& 4: 7-11$

Dhar ON, Rakhecha PR, Mandal BN, Sangam RB (1981b) The rainstorm which caused Morvi dam disaster in August, 1979. Hydrol Sci Bull 26(1):71-81

Du J, Fang J, Xu W, Shi P (2013) Analysis of dry/wet conditions using the standardized precipitation index and its potential usefulness for drought/flood monitoring in Hunan Province China. Stoch Environ Res Risk Assess 27(2):377-387

Egan JP (1975) Signal detection theory and ROC analysis. Academic, New York, pp 266-268

Esteves LS (2013) Consequences to flood management of using different probability distributions to estimate extreme rainfall. J Environ Manag 115:98-105

Feng CC, Wang YC (2011) GIS science research challenges for emergency management in southeast Asia. Nat Hazards 59:597-616

Fernandez DS, Lutz MA (2010) Urban flood hazard zoning in Tucumán Province, Argentina, using GIS and multicriteria decision analysis. Eng Geol 111:90-98. https://doi.org/10.1016/j.engge o.2009.12.006

Gupta S, Javed A, Dutt D (2003) Economics of flood protection in India. Nat Hazards 28:199-210

Haghizadeh A, Siahkamari S, Haghiabi AH, Rahmati O (2017) Forecasting flood-prone areas using Shannon's entropy model. J Earth Syst Sci 126:39. https://doi.org/10.1007/s12040-017-0819-x

Haq M, Akhtar M, Muhammad S, Paras S, Rahmatullah J (2012) Techniques of remote sensing and GIS for flood monitoring and damage assessment: a case study of Sindh province, Pakistan. Egypt J Remote Sens Space Sci 15:135-141

Jaafari A, Najafi A, Pourghasemi HR, Rezaeian J, Sattarian A (2014) GIS-based frequency ratio and index of entropy models for landslide susceptibility assessment in the Caspian forest, northern Iran. Int J Environ Sci Technol 11(4):909-926

Jaiswal RK, Mukherjee S, Krishnamurthy J, Saxena R (2003) Role of remote sensing and GIS techniques for generation of groundwater prospect zones towards rural development-an approach. Int J Remote Sens 24:993-1008

Jebur MN, Pradhan B, Tehrany MS (2014) Optimization of landslide conditioning factors using very high-resolution airborne laser

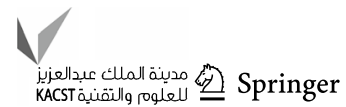


scanning (LiDAR) data at catchment scale. Remote Sens Environ 152:150-165

Khosravi K, Nohani E, Maroufinia E, Pourghasemi HR (2016) A GIS based flood susceptibility assessment and its mapping in Iran: a comparison between frequency ratio and weights-ofevidence bivariate statistical models with multi-criteria decisionmaking technique. Nat Hazards. https://doi.org/10.1007/s1106 9-016-2357-2

Kia MB, Pirasteh S, Pradhan B, Mahmud AR, Sulaiman WNA, Moradi A (2012) An artificial neural network model for flood simulation using GIS: Johor River Basin Malaysia. Environ Earth Sci 67(1):251-264

Konadu DD, Fosu C (2009) Digital elevation models and GIS for watershed modelling and flood prediction-a case study of Accra Ghana. In: Yanful EK (ed) Appropriate technologies for environmental protection in the developing world. Springer, Berlin, pp 325-332

Lee S, Talib JA (2005) Probabilistic landslide susceptibility and factor effect analysis. Environ Geol 47(7):982-990

Lee MJ, Kang JE, Jeon S (2012) Application of frequency ratio model and validation for predictive flooded area susceptibility mapping using GIS. In: IEEE international geoscience and remote sensing symposium (IGARSS), Munich, pp 895-898

Li XH, Zhang Q, Shao M, Li YL (2012) A comparison of parameter estimation for distributed hydrological modelling using automatic and manual methods. Adv Mater Res 356-360:2372-2375

Liao X, Carin L (2009) Migratory logistic regression for learning concept drift between two data sets with application to UXO sensing. IEEE Trans Geosci Remote Sens 47:1454-1466

Manandhar B (2010) Flood plain analysis and risk assessment of Lothar Khola, Nepal. Unpublished Ph.D. thesis, Tribhuvan University, Nepal

Merz B, Kreibich H, Thieken A, Schmidtke R (2004) Estimation uncertainty of direct monetary flood damage to buildings. Nat Hazards Earth Syst Sci 4:153-163

Merz B, Thieken AH, Gocht M (2007) Flood risk mapping at the local scale: concepts and challenges. In: Begum S, Stive MJF, Hall JW (eds) Flood risk management in Europe. Advances in Natural and Technological Hazards Research, vol 25. Springer, Dordrecht, pp 231-251

Messner F, Meyer V (2006) Flood damage, vulnerability and risk perception-challenges for flood damage research. Springer, Amsterdam, pp 149-167

Minea G (2013) Assessment of the flash flood potential of Basca river catchment (Romania) based on physiographic factors. Cent Eur J Geosci 5:344-353

Mishra K (2013) Geomorphological studies and flood risk assessment of Kosi river basin using remote sensing and GIS techniques, $p$ 57. www.iirs.gov.in. Accessed 13 Dec 2018

Mondal S, Maiti R (2013) Integrating the analytical hierarchy process (AHP) and the frequency ratio (FR) model in landslide susceptibility mapping of Shivkhola watershed Darjeeling Himalaya. Int J Dis Risk Sci 4(4):200-212. https://doi.org/10.1007/s1375 3-013-0021-y

Moore ID, Grayson RB, Ladson AR (1991) Digital terrain modelling: a review of hydrological, geomorphological, and biological applications. Hydrol Process 5:3-30

Nampak H, Pradhan B, Manap MA (2014) Application of GIS based data driven evidential belief function model to predict groundwater potential zonation. J Hydrol 513:283-300

Norouzi G, Taslimi M (2012) The impact of flood damages on production of Iran's Agricultural Sector. Middle East J Sci Res 12:921-926

Ohlmacher GC, Davis JC (2003) Using multiple logistic regression and GIS technology to predict landslide hazard in northeast Kansas, USA. Eng Geol 69:331-343
Ozdemir A, Altural T (2013) A comparative study of frequency ratio, weights of evidence and logistic regression methods for landslide susceptibility mapping: Sultan Mountains, SW Turkey. J Asian Earth Sci 64(5):180-197

Pourghasemi HR, Beheshtirad M (2014) Assessment of a data-driven evidential belief function model and GIS for groundwater potential mapping in the Koohrang Watershed, Iran. Geocarto Int 30:662-685

Pourghasemi HR, Pradhan B, Gokceoglu C (2012) Remote sensing data derived parameters and its use in landslide susceptibility assessment using Shannon's entropy and GIS. Appl Mech Mater 225:486-491

Poussin JK, Botzen WJW, Aerts JCJH (2014) Factors of influence on flood damage mitigation behavior by households. Environ Sci Policy 40:69-77

Pradhan B (2010) Landslide susceptibility mapping of a catchment area using frequency ratio, fuzzy logic and multivariate logistic regression approaches. J Indian Soc Remote Sens 38:301-320

Pradhan B, Lee S (2010) Delineation of landslide hazard areas on Penang Island, Malaysia, by using frequency ratio, logistic regression, and artificial neural network models. Environ Earth Sci 60:1037-1054

Pradhan B, Oh HJ, Buchroithner M (2010) Weights-of-evidence model applied to landslide susceptibility mapping in a tropical hilly area. Geomat Nat Hazards Risk 1:199-223

Rahmati O, Haghizadeh A, Pourghasemi HR, Noormohamadi F (2016a) Gully erosion susceptibility mapping: the role of GIS based bivariate statistical models and their comparison. Nat Hazards 82(2):1231-1258

Rahmati O, Haghizadeh A, Stefanidis S (2016b) Assessing the accuracy of GIS-based analytical hierarchy process for watershed prioritization; Gorganrood River Basin, Iran. Water Res Manag 30(3):1131-1150

Rahmati O, Pourghasemi HR, Zeinivand H (2016c) Flood susceptibility mapping using frequency ratio and weights-of-evidence models in the Golastan Province, Iran. Geocarto Int. https://doi. org/10.1080/10106049.2015.1041559

Rahmati O, Zeinivand H, Besharat M (2016d) Flood hazard zoning in Yasooj region, Iran, using GIS and multi-criteria decision analysis. Geomat Nat Hazard Risk. https://doi.org/10.1080/19475 705.2015 .1045043

Regmi N, Giardino J, Vitek J (2010) Modeling susceptibility to landslides using the weight of evidence approach: Western Colorado, USA. Geomorphology 115:172-187

Regmi AD, Devkota KC, Yoshida K, Pradhan B, Pourghasemi HR, Kumamoto T, Akgun A (2013) Application of frequency ratio, statistical index, and weights-of-evidence models and their comparison in landslide susceptibility mapping in Central Nepal Himalaya. Arab J Geosci 7(2):725-742

Saha S (2017) Groundwater potential mapping using analytical hierarchical process: a study on Md. Bazar Block of Birbhum District, West Bengal. Spat Inf Res 25(4):615-626. https://doi.org/10.1007/ s41324-017-0127-1

Samanta RK (2013) Land degradation and water resource management problems in the middle and upper catchment of Subarnarekha river in the part of West Bengal and Orissa. Unpublished Ph.D. thesis, Vidyasagar University, Medinipur

Samanta S, Pal DK, Lohar D, Pal B (2012) Interpolation of climate variables and temperature modeling. Theor Appl Climatol 107(1):3545. https://doi.org/10.1007/s00704-011-0455-3

Samanta RK, Bhunla GS, Shit PK, Pourghasemi HR (2018a) Flood susceptibility mapping using geospatial frequency ratio technique: a case study of Subarnarekha River Basin. Model Earth Syst Environ, India. https://doi.org/10.1007/s40808-018-0427-z 
Samanta S, Pal DK, Palsamanta B (2018b) Flood susceptibility analysis through remote sensing, GIS and frequency ratio model. Appl Water Sci. https://doi.org/10.1007/s13201-018-0710-1

Sarkar D (2018) Identification of channel migration behaviour and delineation of historical channel migration zone of Kulik river within the Barind tract of Indo-Bangladesh. Rev Res 7(11):1-20

Sarkar D, Pal S (2018) Construction of avulsion potential zone model for Kulik River of Barind Tract, India and Bangladesh. Environ Monit Assess 190(5):301. https://doi.org/10.1007/s1066 1-018-6662-y

Shabani F, Kumar L, Esmaeili A (2014) Improvement to the prediction of the USLE K factor. Geomorphology 204:229-234

Sing O, Kumar M (2017) Flood occurrences, damages, and management challenges in India: a geographical perspective. Arab J Geosci 10:102. https://doi.org/10.1007/s12517-017-2895-2

Singh O, Kumar M (2013) Flood events, fatalities and damages in India from 1978 to 2006. Nat Hazards 69:1815-1834

Smith K, Ward R (1998) Floods: physical processes and human impacts. Wiley, Chichester

Sujatha ER, Rajamanickam V, Kumaravel P, Saranathan E (2013) Landslide susceptibility analysis using probabilistic likelihood ratio model—a geospatial-based study. Arab J Geosci 6:429-440

Tehrany MS, Pradhan B, Jebur MN (2013a) Spatial prediction of flood susceptible areas using rule based decision tree (DT) and a novel ensemble bivariate and multivariate statistical models in GIS. J Hydrol 504:69-79

Tehrany MS, Pradhan B, Jebur MN (2013b) Remote sensing data reveals eco-environmental changes in urban areas of Klang Valley, Malaysia: contribution from object based analysis. J Ind Soc Remote 41(4):981-991

Tehrany MS, Lee MJ, Pradhan B, Jebur MN, Lee S (2014a) Flood susceptibility mapping using integrated bivariate and multivariate statistical models. Environ Earth Sci 72:4001-4015

Tehrany MS, Pradhan B, Jebur MN (2014b) Flood susceptibility mapping using a novel ensemble weights-of-evidence and support vector machine models in GIS. J Hydrol 512:332-343

Tehrany MS, Pradhan B, Juber MN (2015) Flood susceptibility analysis and its verification using a novel ensemble support vector machine and frequency ratio method. Stoch Environ Res Risk Assess. https ://doi.org/10.1007/s00477-015-1021-9

Tehrany MS, Shabani F, Jebur MN, Hong H, Chen W, Xie X (2017) GIS-based spatial prediction of flood prone areas using standalone frequency ratio, logistic regression, weight of evidence and their ensemble techniques. Geomat Nat Hazards Risk. https://doi. org/10.1080/19475705.2017.1362038

Tunusluoglu M, Gokceoglu C, Nefeslioglu H, Sonmez H (2008) Extraction of potential debris source areas by logistic regression technique: a case study from Barla, Besparmak and Kapi mountains (NW Taurids, Turkey). Environ Geol 54:9-22

WHO (2003) World Health Organization. Disaster data-key trends and statistics in world disasters report. WHO, Geneva, Switzerland. http://www.ifrc.org/PageFiles/89755/2003/43800-WDR20 03_En.pdf. Accessed 5 Apr 2017

WMO (World Meteorological Organization) (1994) On the front-line: public weather service, WMO No. 816, WMO, Geneva

Xu C, Chen Y, Chen Y, Zhao R, Ding H (2013) Responses of surface runoff to climate change and human activities in the arid region of Central Asia: a case study in the Tarim River Basin, China. Environ Manag 51:926-938

Yilmaz I (2007) GIS based susceptibility mapping of karst depression in gypsum: a case study from Sivas basin (Turkey). Eng Geol 90:89-103

Youssef AM, Pradhan B, Hassan AM (2011) Flash flood risk estimation along the St. Katherine road, southern Sinai, Egypt using GIS based morphometry and satellite imagery. Environ Earth Sci 62:611-623

Yu J, Qin X, Larsen O (2013) Joint Monte Carlo and possibilistic simulation for flood damage assessment. Stoch Environ Res Risk Assess 27(3):725-735

Publisher's Note Springer Nature remains neutral with regard to jurisdictional claims in published maps and institutional affiliations. 